\title{
Evolution acceptance among pre-service primary teachers
}

\author{
Shagufta Arthur
}

\begin{abstract}
Background: The purpose of this study was to investigate evolution acceptance among pre-service primary teachers who opted to study biology $(n=35)$. In this part of their teacher training course they were introduced to the theory of evolution. The study focused on (a) finding out the various degrees of evolution acceptance, (b) reasons behind these choices, (c) views on the origin and biodiversity of life and (d) the perceived impacts of evolution acceptance.
\end{abstract}

Methods: A self-administered survey questionnaire was used which included Likert based items as well as open-ended questions.

Results: In-between positions of evolution acceptance were identified as a fresh contribution to evolution education research. Non-acceptance of evolution was not found in this sample. Students' acceptance of the theory of evolution was identified falling into categories such as strong, reserved and partial-acceptance. Various reasons underlying the students' choices were identified. Six positions on the origin and biodiversity of life were identified in the sample. The atheistic-evolution position was well represented but the modal category was agnostic-evolution; creationists and the other in-between positions were minimally represented. The impacts of evolution acceptance, experienced and perceived, at personal and social level were also identified. The factors which might influence participants' decision making on the theory of evolution were also assembled from participants' responses and previous research.

Conclusion: The educational implication for this study both for the science educators and teachers is to be aware of the positions of their students on evolution acceptance and be prepared to offer educational assistance.

Keywords: Evolution acceptance, Religion, Origin and biodiversity of life, Creationism, Science education

\section{Introduction}

This paper highlights the findings of a study with the preservice primary teachers on their views about the theory of evolution (ToE) when studying biology as a part of their teacher training course. Specific focus was to draw attention to various categories of evolution acceptance, the reasons behind the choices made, students' positions on the views about the origin and biodiversity of life $(\mathrm{OBoL})$ and also students' perceptions of the impact of accepting the theory of evolution on their personal and social lives.

\section{Background}

Interaction between science and religion is complex and varied. Science and religion are two broad explanatory systems and relationship between them is in a constant

\footnotetext{
Correspondence: Shagufta.arthur@gmail.com
}

University of Glasgow, Glasgow, UK state of change (Alexander 2007). They offer answers to a number of fundamental questions. As a result they compete for 'explanatory space' potentially causing a conflict when the domains of application overlap (Preston and Epley 2009). Some people resolve with conflict by considering science and religion to be applicable to two separate domains (e.g. Gould 2002). Others believe that they can be reconciled as compatible systems (Collins 2006) and still others regard them as inherently opposed ideologies (Dawkins 2006).

A number of religious and non-religious worldviews are present in society, and there are multiple ways of conceptualising the notion of a supernatural being, usually referred to as God (Peter 2007). Religious orientations affect attitudes on science, on environmental concerns and specifically on acceptance of the ToE (Orchard 1997; Martin 2010; Yasri and Mancy 2010; Bishop and Anderson 
1990; Downie and Barron 2000; Evans 2011; Brem, Ranney and Schindel 2003; Sinatra et al. 2003; Mazur 2004; Mansour 2008; Smith 2010; Wiles and Alters 2011; Winslow, Staver \& Scharmann, 2011). As a result of these tensions between religious and scientific explanations on the origin and biodiversity of life, Coyne (2009) claimed that not any other theory in the history of science has simultaneously caused more fascination and fury than the ToE.

Although most leaders of mainstream religion have largely acknowledged that there is no substantial conflict between the ToE and their religious percepts (Zimmerman 2010) many individuals still have issues with accepting the ToE (Mansour 2008; Smith 2010 a, b; Allmon 2011) and relating it to their religious views (Meadows, Doster and Jackson 2000; Chandi and Mancy 2011).

The ToE is one of the most important theories in biology and yet a most controversial and problematic one to teach and learn. In education research, there are varied opinions about the teaching goal of science education regarding the ToE. To some (Lawson and Weser 1990; McKachie, Lin and Strayer 2002) acceptance of evolution should be an educational goal but others (Ingram and Nelson 2006; Smith and Seigel 2004; Smith 2010a) regard understanding the theory as more important than its acceptance. There has also been a debate about the acceptance and rejection of the ToE. It is widely recognised that acceptance/rejection is not just an 'all-or-nothing' option (Smith 2010b).

Smith (2010a) reported that the evolution acceptance is an ill-defined construct in science education. He identified at least five meanings of evolution acceptance used in evolution education research by different researchers. He argued that this multiplicity of meaning has contributed to contradictory results in different studies. At the moment MATE (Measure of Attitude towards the Theory of Evolution), with 20 items is a widely used measure of evolution acceptance. However, Smith (2010a) voiced a concern that MATE conflates knowledge of the ToE with evolution acceptance. He proposed a single-item measure which is different from MATE, firstly because it is an abbreviated item of measure to appraise the validity of the ToE and secondly because it provides various options to choose from to identify views on the validity of the ToE. Smith's proposed Likert based measure of evolution acceptance provides options with more depth and meaning and is more reflective and indicative of participants' views. In this study I preferred to respond to Smith's call to contribute to the debate in evolution education research by making a distinction between knowledge and acceptance of the ToE. Smith also emphasised the importance of sampling the participants in a way that would allow comparisons of findings across the globe in science education.

Acceptance or rejection of the ToE is mostly associated with the various religious orientations (Smith 2010; Evans
2011; Brem et al. 2003; Downie and Barron 2000). But Allmon (2011), while recognising that the religious factor is an important influence on people's views, did not consider it the only or even the main reason for resistance. Rather he believed that it interacts in complex ways with many other factors.

There are many causes of non-acceptance of evolution. Several classifications of the causes have been proposed in educational research (e.g. Smith 2010a; Wiles and Alters 2011; Allmon 2011). According to Allmon (2011), the multiplicity of causes behind non-acceptance, is not really appreciated by frontline practitioners including scientists, educators, teachers, exhibit designers, film makers and journalists and are not reflected in the material they produce about the ToE. The wide spectrum of causes for non-acceptance of the ToE needs more research.

Another aspect of evolution education research relates to different views on the origin and biodiversity of life (Brem et al. 2003; Scott, 2009; Chandi and Mancy 2011). I consider that these positions identify a relationship between the two explanations (the ToE and the religious belief) about the origin and biodiversity of life. This relationship is part of a wider relationship between science and religion. The relationship between science and religion is not a dichotomous choice but a gradient of views one might take (Mahner \& Bunge, 1996; Barber 1990; Yasri, Arthur, Smith and Mancy (under review); Smith 2010a; Taber et al. 2011). In the same way, evolutionist and creationist positions are not mutually exclusive and diametrically opposed. There is a spectrum of in-between positions.

Scott (2009) presented an elaborate creation/evolution continuum. The continuum has sharp boundaries such as young earth creationism (YEc) and old earth creationism (OEc). However, the separation of various OEc persuasions is less clear cut. Towards the evolution end of the continuum there are two non-theistic evolutionist views.

In a key study by Brem et al. (2003) on the relationship between evolution and creation narrative, a set of Likertscale statements was used. They used five views on the origin and biodiversity of life and developed statements for these views rationalising scientific and religious explanations. Responses to these statements were employed to categorise the respondents. Brem et al. employed various existing views in developing a questionnaire. Yasri and Mancy (2010) further developed and extended it and was used in studies in Thailand and Pakistan (in prepperation). Their extended continuum is an integration of views presented by Scott and the statements of these views by Brem et al. It is a more inclusive and comprehensive set of views. Brem etl al identified five views such as no intelligent design, intelligent initiation of evolution, intelligent intervention in evolution, humans do not evolve 
all other life does and no evolution. They reflect five views from Scott's continuum but other views such as progressive creation, higher taxon creation and agnostic evolution is not presented in Brem et al's continuum. Yasri and Mancy used statements developed by Brem et al. and also some additional views from Scott's continuum. In addition to this they also employed the concept of abiogensis (which was missing in Brem et al's continuum) to mirror the evolution/creation narrative. A comparison of the continuum is given in Table 1 .

I envisage that among those who accept the ToE, they might have different positions on the origin and biodiversity of life. It has also been reported that the intermediate positions, between creation only and evolution, are perceived suspiciously by some (Allmon 2011; Preseten and Epley 2009). Allmon (2011) states that the 'accommodated positions' (intermediate positions) have critics from both, religious and non-religious, sides. Presten and Eply (2009) assert that holding two competing explanations might be impossible but it is also known that holding competing views is possible by compartmentalising them (Meadows et al. 2000). But I argue that not everybody conceives these two explanations as in competition. They may be perceived as complementary. People manage to find ways of reconciling the two explanations by bringing them together in a less conflicting way. However, there is also some evidence that relating the two explanations is not effortless (Meadows et al., 2000; Chandi and Mancy 2011).

Acceptance of the ToE also has consequences (Brem et al. 2003; Chandi and Mancy, 2011). It has been regarded as a threat to humanity both for an individual and for society. Brem et al. (2003) and Tracy et al. (2011) reported that perception of social and personal impacts of accepting the ToE seemed to be overwhelmingly negative. However, Chandi and Mancy (2011) reported that those who accept the ToE do not always see negative impacts. Some see improvements in social life and welcome expansion in science research.
To sum up, this literature review identified some gaps in evolution education research. For instance there is a little documented research on evolution acceptance among primary teachers who actually study the ToE as a part of their teacher training courses. I also responded to calls specifically by Smith (2010a) firstly, to concentrate on the evolution acceptance by excluding the evaluation of evolution knowledge, and secondly to concentrate on a group of participants which would allow the findings to be applicable and useful in science education circle specifically. This research revolved around the following research question.

What is the status of evolution acceptance among a selected group of pre-service primary teachers who opted to study biology as a part of their teacher training course?

To answer the question, specific objectives of this inquiry were to identify

1) categories of evolution acceptance among student teachers,

2) reasons behind various categories of evolution acceptance,

3) positions on the origin and biodiversity of life, and

4) perceived impacts (if any) of evolution acceptance.

\section{Methods}

This study was in the context of pre-service student teachers from a British university. A sample of 35 student teachers was selected from a School of Education. The chosen university in Scotland represents a strong presence of national and international students from various ethnic, religious and non religious backgrounds. This particular school had a history of training teachers for Catholic schools only but now students from all faiths are trained. Sample for this study is from the latter group of students teachers. However, the participants in this study happened to be all British nationals predominantly of Christian faith representing Catholics (46\%), Protestants (25\%), Church of Scotland (11\%) and Church

Table 1 Views on the origin and biodiversity of life

\begin{tabular}{lll}
\hline \multicolumn{1}{c}{ Scott (2009) } & Brem et al. (2003) & Yasri and Mancy (2010) \\
\hline $\begin{array}{l}\text { Flat earthism } \\
\text { Geocentrism }\end{array}$ & No evolution & Creation only \\
$\begin{array}{l}\text { Young earth creationism } \\
\text { Old earth creationism }\end{array}$ & Human creation only & Human creation only \\
& Human creation only & Higher taxon creation only \\
Progressive creationism & & Progressive creationism \\
Evolutionary creationism & & Deistic Evolution \\
Theistic evolutionism & Intelligent initiation of evolution & Theistic evolution \\
Agnostic evolution & Intelligent intervention in evolution & Agnostic evolution \\
Materialist evolution & & Atheistic evolution \\
\hline
\end{tabular}


of Ireland (4\%). The proportion of student teachers who described themselves as practising and non-practising their religion was equal (46\%). Age range of the sample was 18 to 23 years, $89 \%$ of the sample comprised female student teachers.

Student teachers were in the second year of their teacher training course. A new component of science courses had been introduced and students were given a number of options to choose from; 35 students opted to study biology where they were introduced to the ToE. It was a convenience sample as an accessible group of student teachers was approached to identify their views about the ToE. This group of people was chosen because they do not have much exposure to the ToE at school level but they are expected to deal with such issues in the classroom. Primary teachers are an important part of the educational community as they would influence, in the long run, their learners' capacity for relating science and religion.

Data were collected by using a self-administered survey questionnaire. The questionnaire included Likert based items and also open-ended questions (Additional file 1). Students were approached in their classroom. They were presented with a 'plain language statement' about the research study (along with the survey questionnaire). It was made clear to them that their participation was strictly voluntary and that their privacy and identities will be protected. Unfortunately, for some reasons (unknown to the author) only 28 student teachers decided to take part in the survey leaving a small sample for this study. The questionnaire covered other areas of research as well but for this paper only those questions which were particularly related to the ToE and the OBoL were taken into account. It took 30-40 minutes to complete the questionnaire. The survey questions were drawn, integrated and extended from earlier research (Smith 2010a, Brem et al., 2003; Scott, 2009) that have previously been tested, elaborated and modified. The items in the questionnaire addressed the above mentioned objectives.

1. To identify various categories of evolution acceptance, one-item measure proposed by Smith (2010a) was used. Students were presented with a statement about the ToE (Additional file 1). They were given five options and asked to choose one that best expressed their views about the validity of the ToE. The provided options (to choose from) to indicate participants views were worded in such a way that it could identify various categories of evolution acceptance. This item of measure also allowed participants to indicate their view of uncertainty about the ToE. The answers to this question were interpreted as shown in Table 2.

2. To identify the reasons behind various categories of evolution acceptance, Smith's one-item measure was extended by adding an open-ended question to record students' reasons for their choices (Additional file 1).

3. To ascertain positions on the origin and biodiversity of life, a set of ten statements extended by Yasri and Mancy (bringing together Brem et al. and Scott's scales) for presenting a range of views including creation, evolution (and the concept of abiogensis to mirror creation narrative) and other reconciliatory views (which bring both religious and scientific explanation together) was used. This set of statements is not a brand new measure but a slightly modified version (with slight rewording, some additional creation views from Scott and incorporation of the concept of abiogensis along with creation view) of Brem et al. and Scott's scales which have been around in science education for a while and have been checked for their reliability and validity. Out of ten only 8 statements reflected various known views (the other two options 'I do not know' and 'any other' provided students an opportunity to express their uncertainty and report their own view if it was not found in the given eight statements). Students were asked to choose only one statement which best described their position. Eight categories were used to identify students' positions on the origin and biodiversity of life (Table 3).

4. To identify student teachers' views about the possible (the experienced and perceived) consequences of accepting the ToE were investigated by using openended questions. They were asked to record any consequences they have experienced if they have already accepted the ToE. They were also asked to report any consequences they perceive that they would experience, on their personal lives and also on society, as a result of evolution acceptance.

Data analysis involved descriptive statistics. For the openended questions an interpretive approach was adopted which is primarily concerned with the meaning of the text as the researcher understands it (Guba and Lincon, 1995). Using this process of analysis, students' answers were grouped into broad categories. Some of the results of this study are confirmatory, others are exploratory and still others are based on integrated synthesis of the results in the light of the previous research findings.

\section{Results}

The results are presented in relation to each of the specific objectives mentioned above.

\section{Categories of evolution acceptance}

The various categories of evolution acceptance are shown in Table 4. Non-acceptance of evolution was not found in 
Table 2 Options and categories to identify evolution acceptance

\begin{tabular}{|c|c|c|c|c|c|}
\hline & 1 & 2 & 3 & 4 & 5 \\
\hline Options to choose & Strongly accept & Accept with reservation & Do not know & Reject some parts & Strongly reject \\
\hline Corresponding category & Strong-acceptance & Reserved-acceptance & Unsure & Partial-acceptance & Non-acceptance \\
\hline
\end{tabular}

this group; evolution acceptance was represented by $82 \%$ of the sample and the rest showed uncertainty. Evolution acceptance was a heterogeneous group composed of three subcategories (strong, reserved and partial-acceptance). Strong-acceptance and Reserved-acceptance stood out to be the modal categories of equal proportion.

Reasons behind various categories of evolution acceptance Students gave brief accounts on their reasons for evolution acceptance. Quotes from students' responses are presented below and their responses are summarised in Table 5. Grouping these reasons according to the degree of evolution acceptance is unique to this study.

'I agree with the statement but aspects of religion change the strength of agreement.'

'I think the evidence and logic behind it has got to a point where it cannot be ignored and provides better explanation than writings. Although I consider myself as a Catholic, I think science provides the best information because it has been looked into and researched.'

'I have been brought up in a Catholic environment. So I do have some reservations to the modern theory of evolution. Hence through my own reading and research it appears to be a valid and competent theory.'

'I understand that science answers all questions about evolution. I think that the scientific evidence is conclusive.'

'I do not feel that I know enough about either subject to make an academically informed choice. I can only go on my beliefs and while I respect the religious view point I am only comfortable with accepting proven facts not drawn from fictional texts.'

'... This view explains rationally how evolution happened.' 'I accept with reservations because it is the most reasonable explanation of the world, thought it was an idea thought up by man and man can make mistakes and have different ideas. But there is much more evidence to support the modern theory of evolution than hinder it.'

'... there is too much order in the world to be solely down to evolution and therefore I believe that some higher deity exists, not necessarily God, but there must be something because the control in the world is so high.'

'... and there is a lack of other valid theory to contradict the already available theory of evolution.'

'Far too much evidence through fossils and carbon dating, therefore strongly effective as an explanation.'

'The current theory of evolution does not provide links between species. It only shows how one species (animal) has evolved throughout the life span of that species. There is no evidence to support that we all evolved from single celled organism.'

'If you look at evolution, it takes away the speciality of humans, the purpose of life.'

\section{Positions on the origin and biodiversity of life}

A small fraction of students, $18 \%(n=5)$, did not respond to this question. Of the 23 most (17) opted for the evolution end of the spectrum (Table 3), two stood out to be Creation only and a further three were uncertain about their position of this relationship. Agnostic evolution was the modal category; Atheistic evolution was the second highly favoured category in this sample whereas Theistic and Deistic positions were minimally reported.

\section{Views on the impact of evolution acceptance}

There is a little documented research on the experiences students might have on evolution acceptance. Some quotes from students' responses are presented below. Students' views were gathered under three categories. A summary is presented in Table 6.

Table 3 Students' positions on the origin and biodiversity of life

\begin{tabular}{|c|c|c|c|c|c|c|c|c|c|}
\hline Positions & $\begin{array}{l}\text { Creation } \\
\text { only }\end{array}$ & $\begin{array}{c}\text { Human creation } \\
\text { only }\end{array}$ & $\begin{array}{l}\text { Higher Taxon } \\
\text { creation }\end{array}$ & $\begin{array}{c}\text { Progressive } \\
\text { creation }\end{array}$ & $\begin{array}{c}\text { Theistic } \\
\text { evolutionist }\end{array}$ & $\begin{array}{c}\text { Deistic } \\
\text { evolutionist }\end{array}$ & $\begin{array}{c}\text { Agnostic } \\
\text { evolutionist }\end{array}$ & $\begin{array}{c}\text { Atheistic } \\
\text { evolutionist }\end{array}$ & I do not know \\
\hline $\mathrm{N}$ & 2 & 1 & - & - & 1 & 3 & 8 & 5 & 3 \\
\hline$\%$ & $9 \%$ & $4 \%$ & - & - & $4 \%$ & $13 \%$ & $35 \%$ & $22 \%$ & $13 \%$ \\
\hline
\end{tabular}


Table 4 Student teachers' opinions about the modern ToE

\begin{tabular}{llll}
\hline Evolution acceptance & Categories of evolution & N & $\%$
\end{tabular}
acceptance

\begin{tabular}{llll}
\hline Evolution acceptance & Strong-acceptance & 11 & 39 \\
& Reserved-acceptance & 11 & 39 \\
& Partial-acceptance & 1 & 4 \\
Evolution non acceptance & Non-acceptance & 0 & 0 \\
Uncertain & Uncertainty & 5 & 18 \\
\hline
\end{tabular}

\section{Experienced-impacts of evolution acceptance}

'I doubt my faith at times.'

'I have already accepted the theory of evolution and feel no difference.'

'It adapts my view but does not make me neglect my religion.'

'I do find it sometimes clarifies my religion.'

'No Significant effect, I understand its impact on our past, present and future.'

'It plays some part but does not change my religious belief.'

'It allows for further insight and study of the theory itself.'

'I cannot deny either of them. I sway between both explanations. I think there is truth in both.'

\section{Perceived-impacts of future evolution acceptance}

'I am a religious person so it would change my personal life.'
'It would be an issue completely accepting due to religious belief.'

'It would go against the views which were taught to me throughout my earlier education.'

'It would probably contradict my religion and so would confuse my views.'

'No great impact on my personal life.'

'It would help me to understand our past better however I do not believe it would have an impact on my daily life.'

'My family are all quite religious therefore declaring evolution to be correct when we have no idea of how factual it is would not go down well.'

'It would make me question the Catholic/Christian faith, taking a mix of both (although not really correct) would be my own belief.'

'It suggests that you were created by chance, and therefore do not have a purpose.'

\section{Perceived consequences of evolution acceptance on society} 'It would erase culture and make everyone more equal. Not having a religion to follow, however, could impact negatively on some peoples' lives.'

'I think that social and moral development would be stunted without the ethical guidance of religion.'

'There would be less religious belief.'

'It would not affect day to day life, religious cultures may change.'

\section{Table 5 Reasons behind various categories of evolution acceptance}

\begin{tabular}{|c|c|}
\hline Categories of acceptance & Reasons associated with various levels of evolution acceptance \\
\hline \multirow[t]{5}{*}{ Strong-acceptance } & a) The availability of the scientific evidence (fossils, carbon dating) \\
\hline & b) The logical and rational explanation backing the theory \\
\hline & c) Easy to understand as compared to religion \\
\hline & d) Lack of any other valid theory to contradict it \\
\hline & e) Comfort of accepting proven facts \\
\hline \multirow[t]{4}{*}{ Reserved-acceptance } & a) Religion changes the strength of agreement \\
\hline & b) Limited knowledge to make an informed decision \\
\hline & c) Apparent order in the natural world \\
\hline & d) It is a human idea and it can be a mistake \\
\hline \multirow[t]{3}{*}{ Partial-acceptance } & a) Theory does not prove links between species \\
\hline & b) Lack of evidence about a common single celled ancestor \\
\hline & c) It takes away the purpose of life. \\
\hline
\end{tabular}




Categories of impacts

Perceived-impacts

Impacts on society

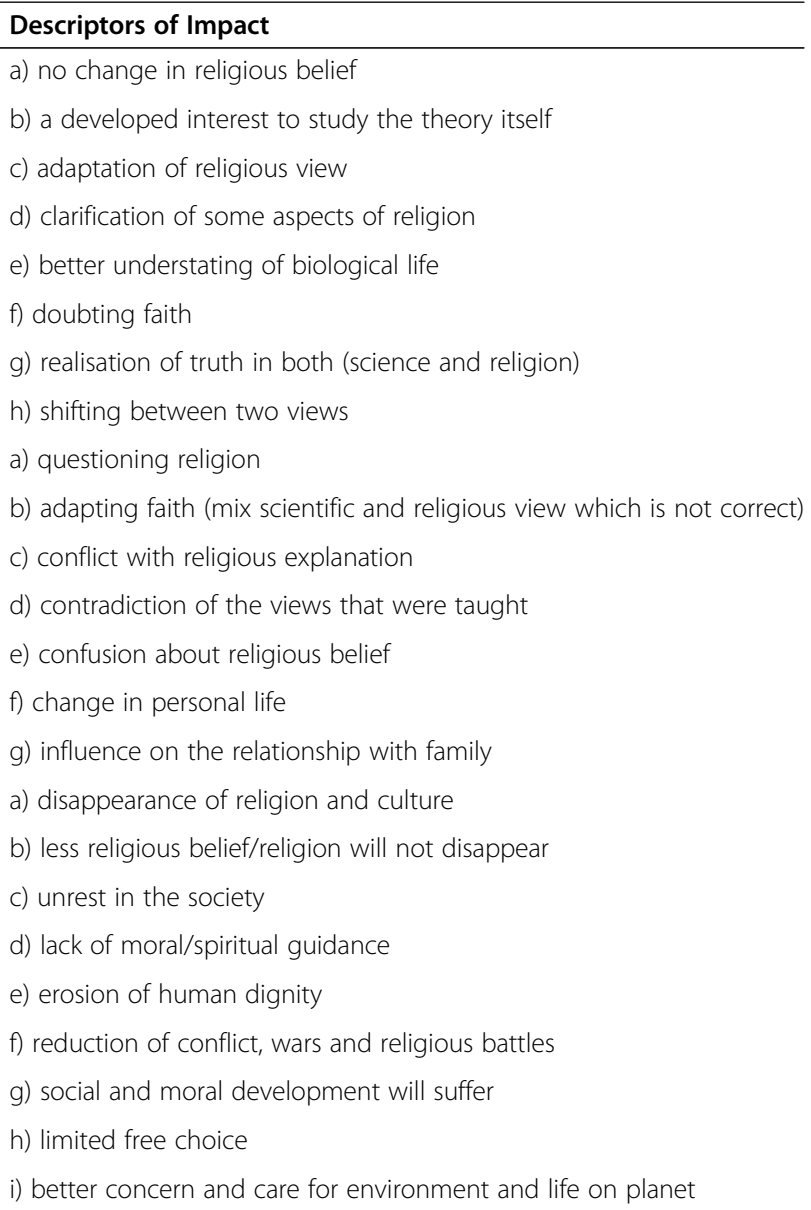

'It would not affect people's day to day life but it would affect their understanding of how life began. It may cause difficulties within religious groups.'

'There would be lack of choice and variation. It may reduce conflict.'

'Unrest, no moral or spiritual grounding and lack of choice for belief limited or restricted.'

'Free choice would be limited. But many unnecessary religious battles would not occur.'

'I feel that it would decrease the amount of different beliefs and so could prevent issues/arguments arising from disagreement. It will also decrease diversity in culture.'

'It would impact religion and could fundamentally remove religion from society which I feel would not be beneficial to society.'
'I believe that it would result in chaos and all purpose of life lost. I believe that if people believed that there was more to it than evolution (like a deity) then we may respect others, our environment and animals than the current states the world is in.'

\section{Discussion}

The findings are discussed in the light of above mentioned objectives.

Firstly, regarding evolution acceptance, this study is consistent with previous studies in showing that evolution acceptance is not a binary choice. However, this study identified various shades of evolution acceptance. No previous research has documented categories of evolution acceptance (other than acceptance and rejection) regarding the validity of the ToE. Non-acceptance was the only category not represented in this sample. However, a $100 \%$ 'strong-acceptance' was not observed either (strong and reserved acceptance were equally represented). It is possible that participants' revealed views about evolution acceptance would not have been their ultimate 
choices as they were still learning about the ToE and also would be growing in their understanding of their religious beliefs over the years to come. For future studies it would be worthwhile to conduct longitudinal research to follow the change or progress in participants' views.

Secondly, this study uniquely identified reasons associated with various categories of evolution acceptance. Reasons associated with strong-acceptance were mostly related to the solid, testable and verifiable empirical nature of scientific knowledge, a regard for scientific evidence, the type of thinking involved (logical and rational) in scientific research, the absence of any other rival theory and the validity of the theory itself. All these reasons indicate the principles of scientific inquiry.

The reasons identified in this study for reservedacceptance are associated with the knowledge content and religious beliefs. From students' perspective, lack of knowledge seems to be an honest response. It would be worthwhile to investigate in longitudinal study how the increased knowledge of the ToE among student teachers leads them to different views. There has been a mixed response to this issue in previous research. Previous research on acceptance and knowledge of evolution has revealed that these constructs are either associated or independent (Nadelson \& Sinatara 2009; Rutledge and Mitchell 2002; Bishop and Anderson 1990; Demastes, Settlage, and Good 1995; Lawson and Worsnop 1992; Sinatra, Southerland, McConaughy, and Demastes 2003). This variation in results calls for future research.

Regarding reserved-acceptance due to religion one must be cautious not to assume that if the mainstream religious leaders accept evolution, the followers will naturally do so. The religious leader might have spent years considering the two explanations on the origin and biodiversity of life. But the student teachers are still climbing the ladder of learning; therefore, their understanding is likely to be different. Science educators and teachers need to be aware of the possible reasons for different categories of evolution acceptance among their students. But at the same time they also need to be patient enough to give students time and resources to allow them to develop an informed understanding of their own.

The reasons associated with partial-acceptance include rejection of some parts of the ToE such as speciation, universal common ancestry and evolution as a self regulatory mechanism. The first two evolutionary concepts were rejected as they were viewed having not enough evidence to support. There seem to be a conflict between these concepts and religious explanations as their acceptance dethrones man, the crown of creation and makes him less human. Although no one mentioned 'religious belief' in the list of reasons in this category but the purpose of life as an issue related to partial-acceptance might have roots in religious beliefs. There was an apprehension that the total acceptance of the ToE would take the purpose of life away, the spiritual aspect of human life which the ToE cannot explain.

Thirdly, relating to the positions on the origin and biodiversity of life, I divided these eight positions into three broader categories presented in Figure 1 (related statements are given in the Additional file 1)

1) Creationist positions do not have any place for scientific explanation on the origin and biodiversity of life (statement $\mathrm{A}=$ Creation only, statement $\mathrm{D}=$ Progressive creation);

2) Evolutionist positions do not have a place for a supreme being. They also take into account purely naturalistic approach involving the concept of abiogenesis and the ToE for the origin of and biodiversity of life (Statement $\mathrm{H}=$ Atheistic evolution, Statement $\mathrm{G}=$ Agnostic evolution).

3) Reconciliatory positions (the in-between positions), which reflect a range of levels of integration of various aspects of the scientific (ToE) and religious explanation, on the origin and biodiversity of life. These views are either (a)Creation-oriented reconciliatory positions which give credit to evolution for the origin of some species but reserve special creation for the others (Statement $\mathrm{B}=$ Human creation only and Statement $\mathrm{C}=$ Higher Taxon creation) and (b) Evolution-oriented reconciliatory positions giving credit to the involvement of a supreme being for the origin of life itself but to the ToE for further evolution and biodiversity of life (Statement $\mathrm{E}=$ Theistic evolution and Statement $\mathrm{F}=$ Deistic evolution).

Even in this small sample, six positions were identified. Creationist-positions were minimally represented but the Evolutionist-positions were most favoured. It is also apparent that Reconciliatory-positions were not favoured even though a great majority of students were Christian and a large proportion of the sample was of practising Christians. The number of students opting for the agnostic-evolutionist position is perhaps an indication that it is not easy to reconcile the two explanations.

It would be valuable to expose students to the idea that many scientists and religious leaders hold a variety of positions including some having both explanations in some sort of a harmony. This approach may lessen their discomfort and unease which probably results in resistance to evolution acceptance.

Finally, regarding impacts of evolution acceptance, specifically, the experienced impacts, two broad categories of impacts were identified: educational and non-educational. The reported non-educational impacts were very 


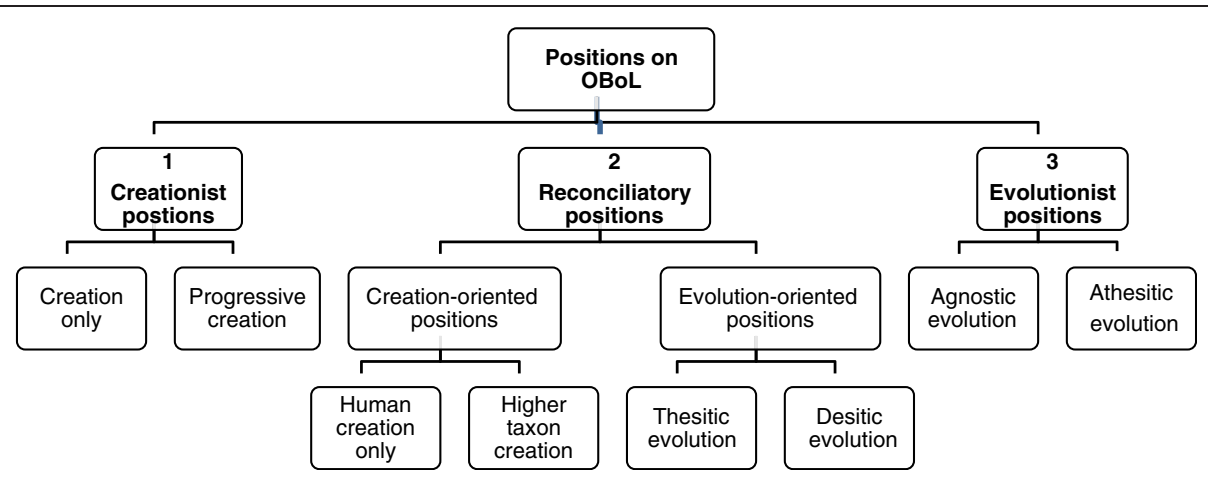

Figure 1 Categories and subcategories of positions on the origin and biodiversity of life (OBoL).

Table 7 A classification of the reported factors that might influence evolution acceptance

\begin{tabular}{|c|c|}
\hline A. Pedagogical factor & Brief description of the factors \\
\hline \multirow[t]{3}{*}{ Fossil related issues } & - Inadequate knowledge of fossil record \\
\hline & - Lack of understanding of the fossil evidence \\
\hline & - Strength of the evidence \\
\hline \multirow[t]{4}{*}{ Knowledge and understanding } & - Not enough knowledge about the ToE \\
\hline & - Incorrect understanding of NOS \\
\hline & - Difficulty to understand mechanism and patterns of evolution \\
\hline & - Insufficient knowledge about ToE as a scientific hypothesis \\
\hline Misconceptions & Misconceptions about the modern ToE \\
\hline Epistemological view & Doubt about socially constructed knowledge \\
\hline Relating science and religion & Difficulty or inability to relate the two systems of knowledge \\
\hline Non-pedagogical Factors & Brief description of the factors \\
\hline \multirow[t]{6}{*}{ Religion oriented issues } & - Issue of relating science and religion \\
\hline & - Literal interpretation of the holy script \\
\hline & - Fear of rejecting God \\
\hline & - Fear of questioning/losing/doubting faith \\
\hline & - Fear of suffusing religion and evolution \\
\hline & - Fear/difficulty of adapting their religious views \\
\hline \multirow[t]{3}{*}{ Spirituality } & - Fear of spiritual void \\
\hline & - Fear of lack of purpose \\
\hline & - Fear of loss of human dignity \\
\hline \multirow[t]{2}{*}{ Psychological issues } & • Essentialism \\
\hline & - Teleological thinking \\
\hline \multirow[t]{4}{*}{ Society oriented factors } & - Social bonds: \\
\hline & - Fear of disapproval from the family \\
\hline & - Fear of betraying the organisational authority (Church) and fellow believers (wider family) \\
\hline & - Concerns about the morality of society \\
\hline Cognitive attributes & $\begin{array}{l}\text { - Difficulty or inability to have Tree thinking, Statistical thinking, Probabilistic thinking, } \\
\text { Cognitive thinking, Logical and Critical thinking }\end{array}$ \\
\hline Political affiliations & Association with who suggest, support or attack the idea. \\
\hline Demographic factors & Race, gender, academic majors etc. \\
\hline
\end{tabular}


personal in nature which perhaps had not been the aim of the science class. These were impacts on students' personal religious beliefs. Out of eight noted impacts, four were directly related to their religious beliefs. These reported experiences are in line with the previous research studies suggesting that the evolution acceptance is not a straightforward phenomenon. It involves adjustments in which both spheres of cognition and emotions are challenged.

Related to perceived impacts of evolution acceptance, students' apprehensions were their worries about their personal beliefs and also that their relationship with their families and the community of believers would change. Students reported a negative perceived association between religion and morality, spirituality and human dignity. Positive impacts included a hope of less conflicts, wars and disagreements.

It is possible that students' perceptions of the impacts of evolution acceptance are the factors which in hindsight might influence the development of students' views. In the light of the results from this study and from the previous studies (Baum and Offiner 2008; Gregory 2008; Sandvik 2008; Meisel 2010; Thagard and Findlay 2009; Allmon 2011; Wiles and Alter, 2011) an integrated classification of factors that might influence evolution acceptance has been presented in Table 7 .

The multiplicity of these factors reflects that learning, understanding and accepting the ToE is neither like learning other subjects nor like any other concept in science. It is different as it deals with the very nature of human beings and their origin. It seems that accepting the ToE is laced with multiple factors which might not operate in isolation but interact with one another like multiple components of a system, and lead to the emergence of a view on the ToE. This interaction of many components might be different for different people therefore the emergence of this interaction would be varied ranging from strong-acceptance to non-acceptance. It would be worthwhile to pursue an investigation to quantify the impact of different causes of the non-acceptance. In conducting such a project I argue that it is important to investigate the views of those who are familiar with the ToE and have studied it.

\section{Conclusion}

To conclude, it might not be feasible to extrapolate the findings of this study around the globe because of the smaller sample size but it it is possible to relate these findings to the participants who are exposed to the ToE elsewhere. For future research, it is recommended to replicate this study with a bigger sample and to investigate, specifically, if there is any association between various levels of evolution acceptance and positions on the origin and biodiversity of life.

\section{Additional file}

Additional file 1: Questionnaire about Learning the Theory of Evolution.

\section{Competing interests}

The author has no competing interest.

\section{Authors' contribution}

The study was designed with my Mentor Dr Mancy. The author collected the data and wrote the final manuscript.

\section{Acknowledgment}

I would like to say thanks to Mr Colin Paterson for reading my manuscript for language correction, to Dr Mancy for commenting on the early version of this paper, and to the reviewers for their criticism and useful suggestion in the production of this article.

Received: 18 January 2013 Accepted: 29 April 2013

Published: 11 June 2013

\section{References}

Alexander, DR. (2007). Models for relating science and religion. Faraday paper, $3,1-4$.

Allmon, WD. (2011). Why don't people think evolution is true? Implications for teaching in and out of the classroom. Evolution: Education and Outreach, 4, 648-665

Barbour, IG. (1990). Religion in an age of science. London: SCM Press.

Baum, DA, \& Offner, S. (2008). Phylogenetics and tree-thinking. The American Biology Teacher, 70, 222-229.

Bishop, BA, \& Anderson, CW. (1990). Student conceptions of natural selection and its role in evolution. Journal of Research in Science Teaching, 27, 415-427.

Brem, SK, Ranney, M, \& Schindel, J. (2003). Perceived consequences of evolution: college students perceive negative personal and social impacts of evolutionary theory. Science Education, 87, 181-206.

Chandi, SS, \& Mancy, R. (2011). Exploring students' personal experiences of learning the theory of evolution at tertiary level. Annual conference in Lyon, France: Research paper presented at ESERA.

Collins, F. (2006). The language of God: a scientist presents evidence for belief. New York: Free Press.

Coyne, JA. (2009). Why evolution is true. Oxford: Oxford University Press.

Dawkins, R. (2006). The God Delusion. London: Transworld Publishers.

Demastes, SS, Settlage, J, \& Good, R. (1995). Students' conceptions of natural selection and its role in evolution: Cases of replication and comparison. Journal of Research in Science Teaching, 32, 535-550.

Downie, JR, \& Barron, NJ. (2000). Evolution and religion: attitude of Scottish first year biology and medical students to the teaching of evolutionary biology. Journal of biological Education, 34, 139-146.

Evans, M. (2011). Cognitive and contextual factors in the emergence of diverse belief system: creation versus evolution. Cognitive Psychology, 42, 217-266.

Gould, J. (2002). Rock of ages: science and religion in the fullness of life. New York: Ballantine Books.

Gregory, TR. (2008). Understanding evolutionary trees. Evolution: Education and Outreach, 1, 121-137.

Guba, EG, \& Lincoln, YS. (1995). Competing paradigms in qualitative research'. In NK Denzin \& YS Lincoln (Eds.), Handbook of Qualitative Research. Thousand Oaks CA: Sage.

Ingram, EL, \& Nelson, CE. (2006). Relationship between achievement and students' acceptance of evolution or creation in an upper-level evolution course. Journal of Research in Science Teaching, 43, 7-24.

Lawson, AE, \& Weser, J. (1990). The rejection of nonscientific beliefs about life: effects of instruction and reasoning skills. Journal of Research in Science Teaching, 27, 589-606

Lawson, AE, \& Worsnop, WA. (1992). Learning about evolution and rejecting a belief in special creation: Effects of reflective reasoning skill, prior knowledge, prior belief and religious commitment. Journal of Research in Science Teaching, 29, 143-166

Mahner, M, \& Bunge, M. (1996). Is religious education compatible with science education? Science and Education, 5, 101-123. 
Mansour, N. (2008). Religious beliefs: A hidden variable in the performance of science teachers in classroom. European Educational Research Journal, 4, 1-20.

Martin, JW. (2010). Compatibility of major U. S. Christian denominations with evolution. Evolution: Education and Outreach, 3, 420-431.

Mazur, A. (2004). Believers and disbelievers in evolution. Politics and Life Sciences, $23,55-61$.

McKeachie, WJ, Lin, YG, \& Strayer, J. (2002). Creationist vs. evolutionary beliefs: effects on Learning Biology. The American Biology Teacher, 64, 189-192.

Meadows, L, Doster, E, \& Jackson, DF. (2000). Managing the conflict between evolution \& religion. The American Biology Teacher, 62, 102-107.

Meisel, RP. (2010). Teaching tree-thinking to undergraduate biology students. Evolution: Education and Outreach, 3, 621-628.

Nadelson, LS, \& Sinatara, GM. (2009). Education professional's knowledge and acceptance of evolution. Evolutionary Psychology, 7(4), 490-516.

Orchard, A. (1997). Assessing the relationship between three Christian theologies of creation and environmental concern. Journal of Beliefs \& Values, 18, 59-67.

Peter, T. (2007). Models of God. Philosophia, 35, 273-288.

Preston, J, \& Epley, N. (2009). Science and God: an automatic opposition between ultimate explanations. Journal of Experimental Social Psychology, 45, 238-241.

Rutledge, ML, \& Mitchell, MA. (2002). High school biology teachers' knowledge: Structure, acceptance \& teaching of evolution. The American Biology Teacher, 64, 21-28.

Sandvik, H. (2008). Tree thinking cannot be taken for granted: challenges for teaching phylogenetics. Theory in Bioscience, 127, 45-51.

Scott, EC. (2009). Evolution Vs Creationism: An Introduction. Berkeley: University of California Press.

Sinatra, GM, Southerland, SA, Mcconaughy, F, \& Demastes, JW. (2003). Intentions and beliefs in students' understating and acceptance of biological evolution. Journal of Research in Science Teaching, 40, 510-528.

Smith, M. (2010a). Current status of research in teaching and learning evolution: I. Pedagogical issues/epistemological issue. Science \& Education, 19, 523-538.

Smith, MU. (2010b). Current status of research in teaching and learning evolution: II. pedagogical issues. Science \& Education, 19, 539-571.

Smith, MU, \& Siegel, H. (2004). Knowing, believing and understanding: what goals for science education? Science and Education, 13, 553-582.

Taber, KS, Billingsley, B, Riga, F, \& Newdick, H. (2011). Secondary Student's response to perceptions of the relationship between science and religion: stances identified from an interview study. Science Education, 95, 1000-1025.

Thagard, P, \& Findlay, S. (2009). Getting to Darwin: obstacles to accepting evolution by natural selection. Science and Education, 19, 625-636.

Tracy, JL, Hart, J, \& Martens, JP. (2011). Death and science: the existential underpinnings of belief in intelligent design and discomfort with evolution. PLOS ONE, 6. http://www.plosone.org/article/info:doi\%2F10.1371\%2Fjournal. pone.0017349

Wiles, JR, \& Alters, B. (2011). Effects of an educational experience incorporating an inventory of factors potentially influencing student acceptance of biological evolution. International Journal of Science Education, 33, 2559-2585.

Winslow, MK, Staver, JR, \& Scharmann, L. (2011). Evolution and personal religious belief: Christian university biology-related major's search for reconciliation. Journal of Research in Science Teaching, 48(9), 1026-1049.

Yasri, P. (June 2010). Mancy, R (2010). Chicago: Perceptions of the relationship between evolutionary theory and Biblical explanations of the origins of life and their effects on the learning of evolution among high school students. Proceedings of the International Conference of the Learning Sciences.

Yasri, P, Arthur, SS, Smith, MU, \& Mancy, R. (Under review). Relating science and religion: a synthesis of typologies and development of a research tool. Journal of research in Science Teaching.

Zimmerman, M. (2010). The Clergy Letter Project. Retrieved April 12, 2010. http:// www.theclergyletterproject.org/pdf/FourthR.pdf.

doi:10.1186/1936-6434-6-20

Cite this article as: Arthur: Evolution acceptance among pre-service primary teachers. Evolution: Education and Outreach 2013 6:20.

\section{Submit your manuscript to a SpringerOpen ${ }^{\odot}$ journal and benefit from:}

- Convenient online submission

- Rigorous peer review

- Immediate publication on acceptance

- Open access: articles freely available online

- High visibility within the field

- Retaining the copyright to your article

Submit your next manuscript at $\gg$ springeropen.com 